Published in final edited form as:

Nature. 2013 September 12; 501(7466): 247-251. doi:10.1038/nature12524.

\title{
A type III effector antagonises death receptor signalling during bacterial gut infection
}

\author{
Jaclyn S Pearson ${ }^{1}$, Cristina Giogha ${ }^{1}$, Sze Ying Ong ${ }^{1}$, Catherine L Kennedy ${ }^{1}$, Michelle \\ Kelly ${ }^{1}$, Keith S Robinson ${ }^{2}$, Tania Wong ${ }^{1}$, Ashley Mansell ${ }^{3}$, Patrice Riedmaier ${ }^{1}$, Clare VL \\ Oates $^{1}$, Ali Zaid ${ }^{1}$, Sabrina Mühlen ${ }^{1}$, Valerie F Crepin ${ }^{2}$, Olivier Marches ${ }^{4}$, Ching-Seng Ang ${ }^{5}$, \\ Nicholas A Williamson ${ }^{5}$, Lorraine A O'Reilly ${ }^{6,7}$, Aleksandra Bankovacki ${ }^{6}$, Ueli Nachbur ${ }^{6}$, \\ Giuseppe Infusini ${ }^{6}$, Andrew I Webb ${ }^{6,7}$, John Silke ${ }^{6,7}$, Andreas Strasser ${ }^{6,7}$, Gad Frankel ${ }^{2}$, \\ and Elizabeth L Hartland ${ }^{1,8,{ }^{*}}$ \\ ${ }^{1}$ Department of Microbiology and Immunology, University of Melbourne, Victoria 3010, Australia \\ ${ }^{2} \mathrm{MRC}$ Centre for Molecular Bacteriology and Infection, Department of Life Sciences, Imperial \\ College London, SW7 2AZ, UK \\ ${ }^{3}$ Centre for Innate Immunity and Infectious Diseases, Monash Institute of Medical Research, \\ Victoria 3010, Australia \\ ${ }^{4}$ Centre for Immunology and Infectious Disease, Blizard Institute, Barts and The London School \\ of Medicine and Dentistry, Queen Mary University of London, London E1 2AT, UK \\ ${ }^{5}$ Bio21 Molecular Science and Biotechnology Institute, University of Melbourne, Victoria 3010, \\ Australia \\ ${ }^{6}$ The Walter and Eliza Hall Institute of Medical Research, Parkville, Victoria 3052, Australia \\ ${ }^{7}$ Department of Medical Biology, University of Melbourne, Victoria 3010, Australia \\ ${ }^{8}$ Murdoch Children's Research Institute, Royal Children's Hospital, Parkville, Victoria 3052, \\ Australia
}

\section{Abstract}

Successful infection by enteric bacterial pathogens depends on the ability of the bacteria to colonise the gut, replicate in host tissues and disseminate to other hosts. Pathogens such as Salmonella, Shigella and enteropathogenic and enterohaemorrhagic E. coli (EPEC and EHEC), utilise a type III secretion system (T3SS) to deliver virulence effector proteins into host cells during infection that promote colonisation and interfere with antimicrobial host responses ${ }^{1-3}$. Here we report that the T3SS effector NleB1 from EPEC binds to host cell death domain

Users may view, print, copy, download and text and data- mine the content in such documents, for the purposes of academic research, subject always to the full Conditions of use: http://www.nature.com/authors/editorial_policies/license.html\#terms

*Correspondence and requests for materials should be addressed to E.L.H. (hartland@unimelb.edu.au). .

Author contributions. J.S.P., C.G., S.Y.O., C.L.K., M.K., K.S.R., T.W., P.R., C.V.O. and A.B. designed and performed the

experiments. V.F.C. and O.M. generated reagents. C.S.A., N.A.W., G.I. and A.I.W. performed mass spectrometry analyses. L.A.O.,

A.Z., S.M., U.N., A.M., A.S., J.S., G.F. J.S.P. and E.L.H. contributed to experimental design. J.S.P., A.S., J.S., G.F. and E.L.H. wrote the manuscript.

Supplementary Information is linked to the online version of the paper at www.nature.com/nature.

The authors declare no competing financial interests. 
containing proteins and thereby inhibits death receptor signalling. Protein interaction studies identified FADD, TRADD and RIPK1 as binding partners of NleB1. NleB1 expressed ectopically or injected by the bacterial T3SS prevented Fas ligand or TNF-induced formation of the canonical death inducing signalling complex (DISC) and proteolytic activation of caspase-8, an essential step in death receptor induced apoptosis. This inhibition depended on the N-GlcNAc transferase activity of NleB1, which specifically modified Arg117 in the death domain of FADD. The importance of the death receptor apoptotic pathway to host defence was demonstrated using mice deficient in the FAS signalling pathway, which showed delayed clearance of the EPEC-like mouse pathogen Citrobacter rodentium and reversion to virulence of an nleB mutant. The activity of NleB suggests that EPEC and other attaching and effacing $(\mathrm{A} / \mathrm{E})$ pathogens antagonise death receptor induced apoptosis of infected cells, thereby blocking a major antimicrobial host response.

\section{Keywords}

EPEC; apoptosis; caspase-8; death domain

Members of the death receptor family such as FAS and TNFR1 contain an intracellular death domain (DD) and require caspase- 8 for the activation of effector caspases and consequent cell death by the extrinsic apoptotic pathway 4,5 . Within seconds of engagement by Fas ligand (FasL), pre-associated FAS trimers undergo multimerisation and recruit the DD containing adaptor protein FADD via heterotypic DD interactions ${ }^{5}$. FADD then recruits pro-caspase- 8 forming the death-inducing signalling complex (DISC), whereupon caspase-8 undergoes conformational change, auto-proteolytic processing and release from the DISC to allow cleavage of cytosolic substrates, including pro-caspase-3 and Bid ${ }^{5}$. Similarly, upon stimulation by TNF, TNFR1 recruits the adaptor protein TRADD and the receptor kinase, RIPK1, leading to NF- $\kappa$ B activation. Alternatively, cell death may be induced via TNFR1 internalisation and formation of a secondary complex that contains TRADD/RIPK1/FADD and caspase-8 6,7 .

Previously, we reported that the EPEC T3SS effector NleB1 inhibited I $\kappa$ B degradation in cells upon stimulation with TNF but not IL-1 $\beta$, suggesting that NleB1 interfered with death receptor signalling ${ }^{8}$. To identify host cell binding partners of NleB1, we screened a yeast-2hybrid cDNA library derived from HeLa cells using NleB1 as bait. FADD and RIPK1, were recovered multiple times. Transformation into a different yeast strain demonstrated that the interaction of NleB1 with FADD and RIPK1 occurred through their respective DD (Fig. 1ac). Studies in transfected HEK293T cells showed that FADD-FLAG, TRADD-FLAG and RIPK1-FLAG co-purified with a GFP-NleB1 fusion protein as well as 2HA-tagged NleB1 translocated during EPEC E2348/69 infection (Fig. 1d and Extended Data Fig. 1a, b). The DD of FADD was required for binding to NleB1 from different A/E pathogens (Fig. 1d and Extended Data Fig. 1b). As TRADD and RIPK1 are critical components of the TNFR1 signalling complex, we investigated the influence of NleB1 on inhibition of the NF- $\kappa \mathrm{B}$ dependent cytokine, IL-8, during EPEC infection. Unlike NleE, a known inhibitor of NF- $\kappa \mathrm{B}$ activation ${ }^{8,9}$, neither NleB1 nor its close homologue NleB2 appeared to inhibit IL-8 production during EPEC infection (Extended Data Fig. 1c). Therefore we focussed our attention on FADD-dependent apoptosis signalling. After treatment with FasL, HeLa cells 
transfected with pGFP-NleB1 showed significantly higher levels of MTT reduction (mitochondrial activity) compared to pEGFP transfected cells (Fig. 1e), suggesting that NleB1 blocked cell death. Immunoblot analysis with an antibody that recognises only cleaved caspase-8, revealed that FasL-induced caspase- 8 cleavage was substantially reduced in HeLa cells transfected with pGFP-NleB1 (Fig. 1f). By immunofluorescence microscopy (IF), fewer cells expressing GFP-NleB1 contained cleaved caspase-8 after treatment with FasL (Extended Data Fig. 1d, e). In contrast, a comparable number of cells contained cleaved caspase-3 in untransfected, GFP and GFP-NleB1 expressing cells treated with tunicamycin (Extended Data Fig. 1e). This indicated that NleB1 had no effect on activation of the intrinsic apoptotic pathway.

NleB from the murine A/E pathogen $C$. rodentium $(\mathrm{CR})$ was recently described as a GlcNAc transferase and a member of the glycogenin family of enzymes ${ }^{10}$. Given the ability of NleB1 to bind FADD and inhibit proteolytic activation of caspase-8, we examined whether FADD was post-translationally modified by NleB1. Following incubation with GST-NleB1 and UDP-GlcNAc, we observed GlcNAc modification of His-FADD (Fig. 2a). This modification was not present upon incubation with an NleB1 catalytic site mutant $\left(\mathrm{NleB} 1_{\mathrm{AAA}}\right)^{10}$. Similar modification of FADD-FLAG occurred upon ectopic expression of GFP-NleB1 in HeLa cells (Extended Data Fig. 1f). Intact protein LC-MS of His-FADD incubated with GST-NleB1 and UDP-GlcNAc revealed a mass shift matching a single GlcNAc modification on FADD (Fig. 2b). Peptide sequencing of multiple spectra from ingel digests unambiguously identified Arg117 as the site of N-GlcNAcylation (Fig. 2c, Extended Data Fig. 2-3, Table S1). This was confirmed by substitution of Arg117 in FADD with alanine, whereas alanine substitution at Ser122 had no impact on NleB-mediated NGlcNAcylation (Extended Data Fig. 4). Arg117 is located at the interface of the FAS-FADD DD interaction and is critical for assembly of the FAS-FADD oligomeric complex and formation of the DISC ${ }^{11,12}$. Accordingly, GFP-NleB1 but not catalytically inactive GFPNleB $1_{\text {AAA }}$ inhibited caspase- 8 activation (Fig. 2 d).

During infection, NleB1 delivered by the EPEC T3SS inhibited FasL-induced caspase-8 activation in HeLa cells. This inhibition was lost in cells infected with an $\operatorname{esc} N$ mutant, that has a non-functional T3SS, or an $\Delta$ nleB1/B2 double mutant (Fig. 2e-g). Complementation of the $\triangle n l e B 1 / B 2$ mutant with nleB1 but not nleB2 restored the ability of EPEC to inhibit caspase-8 activation (Fig. 2e-g), demonstrating that the two NleB proteins have distinct functions. This mirrored our protein interaction studies, which showed that NleB2 did not interact with FADD or TRADD and bound only weakly to RIPK1 (Extended Data Fig. 5ad).

Arg117 in FADD is essential for FAS-FADD and TRADD-FADD DD interactions 11, 12 . Consistent with the role of NleB1 in inhibition of FADD-dependent caspase- 8 activation, an nleB1 mutant was unable to inhibit FasL- or TNF-induced activation of caspase-8 while the complemented strain was as effective as WT EPEC (Fig. 3a and Extended Data Fig. 5e, f). EPEC expressing NleB1 also inhibited FasL-induced apoptosis as measured by propidium iodide (PI) staining (Fig. 3b, c). These phenotypes were not due to differences in adherence (Extended Data Fig. 5g). 
NleB1 GlcNAc transferase activity was required for inhibition of FasL-induced caspase-8 processing during infection (Fig. 3d). To examine the impact of NleB1 on FAS DISC assembly, which precedes caspase- 8 activation, we immunoprecipitated the FAS receptor complex from infected HeLa cells treated with FasL (Fig. 3e). Prior infection of cells with EPEC substantially inhibited FasL-induced DISC formation and this required NleB1 GlcNAc transferase activity (Fig. 3e).

We next examined the effect of NleB on inhibition of caspase- 8 processing in vivo by infecting WT C57BL/6 mice with CR or an nleB mutant of CR and staining tissue sections for cleaved caspase- 8 . While few cells were positive for cleaved caspase- 8 during CR infection, significant numbers of cells were positive for cleaved caspase- 8 during infection with the $n l e B$ mutant (Fig. 4a). Many of these caspase-8 positive cells were present as sloughed cells in the gut lumen (Extended Data Fig. 6a).

The observation that NleB1 inhibited FasL-induced caspase-8 cleavage suggested that FASmediated apoptosis contributes to host defence against A/E pathogens. We tested this by infecting FAS-deficient $F a s^{l p r / l p r}$ mutant mice with $\mathrm{CR}^{13}$. As shown previously, $n l e B$ was essential for efficient colonisation of WT C57BL/6 mice ${ }^{14}$ (Fig. 4b). Although there was no difference in faecal shedding of $\mathrm{CR}$ between $\mathrm{C} 57 \mathrm{BL} / 6$ and $\mathrm{Fas}{ }^{\mathrm{lpr} / \mathrm{pr}}$ mice during the acute phase of infection (first 12 days) (Fig. 4b), Fas ${ }^{l p r / p r}$ mice developed severe, watery diarrhoea (Fig. 4c). In addition, CR penetrated the crypts in Fas ${ }^{l p r / p r}$ mice, unlike in C57BL/6 mice where the bacteria were predominantly located at the tips of the villi (Fig. 4d). To study the resolving phase of infection (post day 12), C57BL/6 and Fas ${ }^{l p r / p r}$ mice were infected with a lower dose of CR to avoid the rapid onset of severe diarrhoea and monitored for up to 33 days. Fas ${ }^{l p r / p r}$ mice were impaired in their ability to clear CR compared to C57BL/6 mice (Fig. 4e and Extended Data Fig. 6b).

The development of severe diarrhoea in CR-infected Fas ${ }^{l p r / p r}$ mice was unexpected and sections of colon from mice infected with $\mathrm{CR}$ for 10 days were examined to identify differences in pathology between Fas ${ }^{l p r / p r}$ mice and C57BL/6 mice. Histological analysis of colons from Fas ${ }^{l p r / p r}$ mice revealed greater erosion of the epithelium (tissue damage) as well as increased colon weight and crypt height compared to C57BL/6 mice (measures of CR-induced intestinal hyperplasia ${ }^{14}$ ) (Extended Data Fig. 7a-d). In addition, Fas ${ }^{l p r / p r}$ mice showed more pronounced neutrophil infiltration, which penetrated across the muscularis mucosa (Extended Data Fig. 7e). Similar phenotypes were observed in FasL-deficient Fas ${ }^{\text {gld/gld }}$ mice and Bid-deficient mice (Fig. 4d, e and Extended Data Fig. 8). Bid is not required for FasL-induced apoptosis in lymphoid cells, but is required for FasL-induced apoptosis in several other cell types ${ }^{15,16}$. This suggests that FAS signalling in epithelial cells rather than lymphoid cells limits CR-induced colitis.

We reasoned that if NleB interfered with FAS-mediated apoptosis signalling during infection, then $\mathrm{CR}$ nleB mutant bacteria would no longer be attenuated in mice that carry defects in this apoptosis pathway. Indeed, Fas ${ }^{l p r / p r}$ mice infected with the nleB mutant showed comparable levels of bacterial colonisation and severity of diarrhoea compared to their littermates infected with CR (Extended Data Fig. 6b and 9a, b). The same was not true 
for espI or espF mutants of CR, which retained their known colonisation defects in Fas ${ }^{l p r / l p r}$ mice (Extended Data Fig. 9c, d) ${ }^{17}, 18$.

During infection with $\mathrm{A} / \mathrm{E}$ pathogens, the predominant site of NleB activity is in enterocytes where the translocation of bacterial effector proteins occurs ${ }^{1}$. NleB-mediated inhibition of FasL/FAS-induced apoptosis may prolong host cell attachment and faecal shedding of the pathogen. Indeed NleB is associated with the transmission of CR amongst littermates ${ }^{19}$ and is epidemiologically associated with outbreaks of HUS caused by EHEC ${ }^{20,21}$. Conversely, the reduced colonisation of $\mathrm{C} 57 \mathrm{BL} / 6$ mice by $\mathrm{CR}$ nleB mutants and increased numbers of activated caspase- 8 positive cells may reflect partial protection by the FAS apoptotic pathway through the elimination of infected cells ${ }^{14}$. This is consistent with the prolonged shedding of CR in FAS-deficient animals compared to C57BL/6 mice. The increased intestinal pathology observed in CR-infected FAS-, FasL- and Bid-deficient mice has also revealed a function for the FAS apoptotic pathway in limiting the extent of colitis during gastrointestinal infection. This aggravation of disease may be mirrored in humans, as nucleotide polymorphisms in the FASLG gene, encoding FasL, have been associated with the development of inflammatory bowel disease ${ }^{22}$. In summary, the discovery of a bacterial T3SS effector that specifically modifies DD containing proteins through a novel post translational modification and thereby inhibits death receptor mediated apoptosis has revealed a new virulence mechanism in bacterial infection.

\section{METHODS}

\section{Bacterial strains, plasmids, yeast strains and growth conditions}

The bacterial strains, yeast strains and plasmids used in this study are listed in Table S2. All PCR primers are listed in Table S3. Bacteria were grown at $37^{\circ} \mathrm{C}$ in Luria-Bertani (LB) medium or Dulbecco's modified Eagle's medium (DMEM) (GIBCO, NY) where indicated and supplemented with ampicillin $(100 \mu \mathrm{g} / \mathrm{mL})$, kanamycin $(100 \mu \mathrm{g} / \mathrm{mL})$, nalidixic acid (50 $\mu \mathrm{g} / \mathrm{mL})$ or chloramphenicol $(25 \mu \mathrm{g} / \mathrm{mL})$ when necessary. Yeast strains were grown at $30^{\circ} \mathrm{C}$ in YPD (yeast extract/peptone/dextrose) medium or yeast nitrogen minimal medium supplemented with $2 \%$ glucose and amino acids including histidine $(20 \mu \mathrm{g} / \mathrm{mL})$, methionine $(20 \mu \mathrm{g} / \mathrm{mL})$, tryptophan $(20 \mu \mathrm{g} / \mathrm{mL})$, adenine $(20 \mu \mathrm{g} / \mathrm{mL})$, uracil $(20 \mu \mathrm{g} / \mathrm{mL})$ and leucine (30 $\mu \mathrm{g} / \mathrm{mL}$ ) when necessary. For infection of HeLa cells, overnight cultures of EPEC grown in LB medium were subcultured 1:50 into DMEM and grown statically for 3-4 h at $37^{\circ} \mathrm{C}$ with $5 \% \mathrm{CO}_{2}$. The optical density $\left(A_{600}\right)$ of the bacterial cultures was measured to standardize the inoculum before infection. Cultures were induced with $1 \mathrm{mM}$ isopropyl- $\beta$-Dthiogalactopyranoside (IPTG) for $30 \mathrm{~min}$ prior to infection.

\section{Construction of NleB, TRADD, RIPK1 and FADD expression vectors}

The plasmids and primers used in this study are listed in Table S2 and S3, respectively. The nleB1 gene from EPEC E2348/69 (GenBank Accession CAS10779), nleB1 from EHEC O157:H7 EDL933 (GenBank Accession NP_289553.1) and nleB from C. rodentium (GenBank Accession NC_013716.1) were amplified from genomic DNA by PCR using the primer pairs $\mathrm{NleB} 1_{\mathrm{F}} / \mathrm{NleB} 1_{\mathrm{R}}, \mathrm{NleB} 1_{\mathrm{EHF}} / \mathrm{NleB} 1_{\mathrm{EHR}}$ or $\mathrm{NleB} \mathrm{CRF}_{\mathrm{C}} / \mathrm{NleB} \mathrm{CRR}_{\mathrm{R}}$ respectively and ligated into EcoRI/BamHI digested pEGFP-C2 to generate $\mathrm{N}$-terminal GFP fusions to NleB 
(GFP-NleB1, GFP-NleB $1_{\text {EHEC }}$, GFP-NleB ${ }_{\mathrm{CR}}$ ). The nleB2 gene was amplified from EPEC E2348/69 genomic DNA (GenBank Accession CAS08589) using primer pairs NleB2 $\mathrm{F} /$ $\mathrm{NleB} 2{ }_{R}$ and ligated into EcoRI/BamHI digested pEGFP-C2. To generate the complementing vectors, pNleB1 and pNleB2, nleB1 and nleB2 were amplified from EPEC E2348/69 genomic DNA by PCR using the primer pairs $\mathrm{NleB} 1_{\mathrm{F}} / \mathrm{NleB} 1_{\mathrm{R}}$ and $\mathrm{NleB} 2_{\mathrm{F}} / \mathrm{NleB} 2_{\mathrm{R}}$ and ligated into EcoRI/BamHI digested pTrc99A. To create pNleB1-2HA and pNleB2-2HA, nleB1 or nleB2 was amplified from EPEC E2348/69 genomic DNA by PCR using the primer pairs $\mathrm{NleB} 1_{\mathrm{F}} / \mathrm{NleB} 1_{\mathrm{R}-2 \mathrm{HA}}$ and $\mathrm{NleB} 2_{\mathrm{F}} / \mathrm{NleB} 2_{\mathrm{R}-2 \mathrm{HA}}$, respectively, and ligated into EcoRI/BamHI digested pTrc99A. To generate GST tagged NleB, nleBl was amplified from EPEC E2348/69 genomic DNA by PCR using the primer pairs NleB1 $1_{\mathrm{F}} / \mathrm{NleB} 1_{\text {PGEXR }}$ and ligated into EcoRI/SalI digested pGEX-4T-1.

TRADD-FLAG was kindly provided by Dr. Jürg Tschopp (University of Lausanne, Lausanne, Switzerland). FADD-FLAG and RIPK1-FLAG were provided by Dr. Ashley Mansell. To generate FADD ${ }_{\triangle D D}-\mathrm{FLAG}$, the coding region for amino acids 1-96 of FADD was amplified by PCR from FADD-FLAG using the primer pairs $\mathrm{FADD}_{\mathrm{F}} / \mathrm{FADD}_{\triangle \mathrm{DDR}}$ and ligated into EcoRI/BamHI digested p3XFLAG-Myc-CMV to generate an N-terminal $3 \times$ FLAG fusion to FADD ${ }_{\text {aal-96 }}\left(\mathrm{FADD}_{\Delta \mathrm{DD}}\right.$-FLAG). To generate His-FADD, FADD was amplified from FADD-FLAG using the primer pairs FADD $_{\text {HISF }} /$ FADD $_{\text {HISR }}$ and ligated into BamHI/SalI digested pET28a.

To generate pGBT-NleB1, nleB1 was amplified from EPEC E2348/69 or EHEC O157:H7 EDL933 genomic DNA by PCR using primer pairs NleB $1_{\mathrm{EPGBTF}} / \mathrm{NleB} 1_{\mathrm{R}}$ or NleB $1_{\mathrm{EHGBTF}} /$ NleB1 $1_{\mathrm{EHR}}$ (pGBT-NleB1 and pGBT-NleB1 $1_{\mathrm{EH}}$ ). The PCR products were digested with SmaI/EcoRI and EcoRI/BamHI, respectively and ligated into pGBT9. The plasmids pGAD$F_{A D D} D_{D E D}$ and pGAD-FADD ${ }_{D D}$ were generated from the template pGAD-FADD recovered from the cDNA library screen using primer pairs FADD $_{\mathrm{GADF}} / \mathrm{FADD}_{\mathrm{DEDR}}$ and $\mathrm{FADD}_{\mathrm{DDF}} /$ FADD $_{\mathrm{GADR}}$, respectively. The FADD $\mathrm{DED}_{\mathrm{D}}$ and FADD $_{\mathrm{DD}}$ PCR products were digested with EcoRI/HindIII and EcoRI/SalI, respectively, and ligated into pGAD424. The pGADRIPK $1_{\text {DD }}$ plasmid was generated using primers RIPK $1_{\text {DDF }} /$ RIPK$_{\text {GADR }}$ using $\mathrm{pGAD-}$ RIPK1 recovered from the cDNA library screen as template DNA, and cloned via the EcoRI and BamHI restriction sites.

\section{Construction of non-polar deletion mutants}

C. rodentium strain ICC169 $\Delta$ nleB (ICC911) was constructed using the lambda Red-based mutagenesis system ${ }^{23}$. The $n l e B$ gene was replaced by a kanamycin resistance cassette following integration of a linear PCR product generated using the primers pair $\mathrm{crNleB}$ pKD4-Fw/crNleB-pKD4-Rv, which contain 50 nucleotide homology extensions corresponding to regions in $5^{\prime}$ and $3^{\prime}$ of the $n l e B$ open reading frame and priming sequences for the kanamycin cassette of plasmid pKD4 (underlined) ${ }^{23}$. The PCR product was DpnIdigested to remove residual template, gel purified and electroporated into ICC169 carrying the temperature-sensitive lambda Red helper plasmid pKD46 following induction of Lambda Red recombinase with $10 \mathrm{mM} \mathrm{L}$-arabinose at $30^{\circ} \mathrm{C}$. Deletion mutant of $C$. rodentium nleB was confirmed by PCR and DNA sequencing and the growth rates of the mutant and parental strains were assessed in rich and minimal media. The $C$. rodentium 
strains ICC169 $\Delta e s p I$ (ICC179) and ICC169 $\Delta e s p F$ (ICC177) has been described previously ${ }^{17}$. EspI binds to Sec24 and inhibits COPII-dependent vesicle trafficking while EspF is a multifunctional effector that has been associated with destabilisation of mitochondria, induction of apoptosis, activation of sorting nexin 9 and disruption of tight junctions ${ }^{1}$. These mutants were chosen as controls as they exhibit varying degrees of attenuation in the mouse model of $\mathrm{CR}$ infection and have functions unrelated to NleB.

The EPEC E2348/69 nleB1 mutant was created with the one step PCR lambda Red method using primers NleB1 E69FRT $\mathrm{F}_{155}$ and NleB1 E69FRT $\mathrm{R}_{\mathrm{R} 156}$. $\mathrm{pKD} 3$ was used as template DNA to amplify the chloramphenicol cassette. The cassette was electroporated into WT EPEC E2348/69 and positive clones were selected on LB agar with $5 \mu \mathrm{g} / \mathrm{mL}$ chloramphenicol. The mutations were checked by PCR using primer pairs from outside and inside the mutation. The EPEC E2348/69 nleB2 mutant was created using primers NleB2 E69FRT $_{\mathrm{F} 115}$ and NleB2 E69FRT $_{\mathrm{R} 116}$. pKD4 was used as template DNA to amplify the kanamycin cassette. The cassette was electroporated into WT EPEC E2348/69 and positive clones selected for on LB agar with $50 \mu \mathrm{g} / \mathrm{mL}$ kanamycin. The mutations were checked by PCR with a combination of primers from outside and inside the mutation. The EPEC E2348/69 nleB1/nleB2 double mutant was generated using the one step PCR method by amplifying the nleB2 mutation from the nleB2 mutant with primers $\mathrm{NleB} 2_{212}$ and $\mathrm{NleB} 2_{213}$. The PCR product was transferred into the $n l e B 1$ mutant strain by electroporation. Mutants were first selected on LB agar plates with $20 \mu \mathrm{g} / \mathrm{mL}$ of kanamycin and then grown with chloramphenicol $(25 \mu \mathrm{g} / \mathrm{mL})$ and kanamycin $(50 \mu \mathrm{g} / \mathrm{mL})$ to select for nleB1 and nleB2 allelic replacement.

\section{Site-directed mutagenesis}

The His-FADD $\mathrm{R}_{117 \mathrm{~A}}$ and His-FADD $\mathrm{S}_{122 \mathrm{~A}}$ mutants, and the NleB1 mutants, pNleB1 $1_{\mathrm{AAA}}$, GFP-NleB1 $1_{\mathrm{AAA}}$ and pGEX-NleB1 $1_{\mathrm{AAA}}$ were generated using the Stratagene Quickchange II Site-Directed Mutagenesis Kit. FADD $_{\mathrm{R} 117 \mathrm{~A}}$ and $\mathrm{FADD}_{\mathrm{S} 122 \mathrm{~A}}$ were generated by PCR using

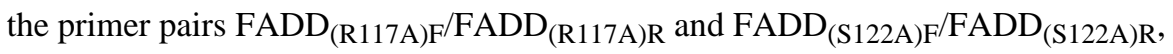
respectively with His-FADD as template DNA. For the NleB mutants, pNleB1, GFP-NleB1 or pGEX-NleB1 were used as template DNA and amplified by PCR using the primer pair pNleB1 $1_{(\mathrm{AAA}) \mathrm{F}} / \mathrm{pNleB} 1_{(\mathrm{AAA}) \mathrm{R}}$. Plasmids were digested with $\mathrm{DpnI}$ at $37^{\circ} \mathrm{C}$ overnight before subsequent transformation into the appropriate E. coli strain.

\section{Yeast two-hybrid screening and $\beta$-galactosidase assay}

NleB1 from EPEC strain E2348/69 (GenBank Accession CAS10779) and NleB1 from EHEC O157:H7 strain EDL933 (GenBank Accession NP_289553.1) were used as bait. The BD Matchmaker pre-transformed HeLa cDNA library (Clontech, CA, USA) was screened according to the manufacturer's protocols (Clontech PT3183-1 manual) to identify HeLa proteins interacting with NleB. The yeast strain AH109 (MATa) was transformed with pGBT-NleB using the LiAc method and mated with Y187 (MATa) carrying the cDNA library in pGADT7 Rec plasmid. The mating mixtures were plated onto quadruple drop-out plates ( $\mathrm{Trp}^{-}, \mathrm{Leu}^{-}, \mathrm{Ade}^{-}, \mathrm{His}^{-}$) to select for diploids expressing reporter genes. The pGADT7-Rec-cDNA plasmids were selectively rescued from those diploids with positive 
protein interactions into $E$. coli $\mathrm{KC} 8$. The pGADT7-Rec-cDNA plasmids were then sequenced using primer Rec744 to identify the cDNA inserts.

$\beta$-galactosidase assays were performed according to the manufacturer's protocols (Clontech PT3024-1 manual). Briefly, pGADT7-Rec plasmid alone or with pGBT-NleB (or pGBT9, pGAD-FADD, pGAD-FADD ${ }_{\mathrm{DED}}$, $\mathrm{pGAD}$ FADD $_{\mathrm{DD}}$ when necessary) were transformed into Saccharomyces cerevisiae strain PJ69-4A using the LiAc method. Transformants were selected on $\mathrm{Trp}^{-} \mathrm{Leu}^{-}$plates and grown to an optical density $\left(A_{600}\right)$ of 0.6 before lysis and assay for the level of $\beta$-galactosidase activity using ONPG as a substrate. Data are from at least three biological replicates performed in triplicate.

\section{Bacterial adherence assay}

Standard lines of HeLa and HEK293T cells are maintained in our laboratory and regularly tested for mycoplasma contamination. To assess the level of bacterial replication during infection and treatment with FasL, bacterial cultures grown in DMEM for were standardised by measurement of $\mathrm{OD}_{600}$ and plated on selective media for assessment by viable count. HeLa cell monolayers were infected in duplicate with the same cultures for $3 \mathrm{~h}$ before being incubated for $1.5 \mathrm{~h}$ in media supplemented with or without $20 \mathrm{ng} / \mathrm{mL} \mathrm{Fc} \gamma$-FasL. Following treatment, cells were washed three times and attached bacteria were resuspended in DMEM by pipetting and subsequently spread on selective media for assessment of bacterial viable count. Data are from at least three biological replicates performed in triplicate.

\section{Immunoprecipitation and detection of HA-, GFP-, FLAG-tagged proteins}

All immunoprecipitation experiments were performed as at least three biological replicates. For immunoprecipitation by GFP-Trap®-M (Chromotek, Germany), HEK293T cells were grown in $10 \mathrm{~cm}$ tissue culture dishes (Greiner Bio One) and co-transfected with GFP-NleB1 or GFP-NleB2 in combination with RIPK1-FLAG, TRADD-FLAG, FADD-FLAG or $\mathrm{FADD}_{\triangle \mathrm{DD}}$-FLAG. Following transfection (after 18-24 h), lysis and immunoprecipitation were carried out according to instructions for immunoprecipitation of GFP-fusion proteins provided by the GFP-Trap®-M supplier.

For immunoprecipitation of $2 \times$ hemagglutinin (HA) tagged proteins, HeLa cells cultured in $\mathrm{T}-75 \mathrm{~cm}^{2}$ tissue culture flasks (Corning, USA) were first transfected with FADD-FLAG, RIPK1-FLAG or TRADD-FLAG expression constructs for $18 \mathrm{~h}$ followed by infection with various EPEC derivatives for 90-120 min. Cells were then washed three times with cold PBS and lysed in $1 \mathrm{~mL}$ cold lysis buffer (1\% Triton X-100, $50 \mathrm{mM}$ Tris- $\mathrm{HCl} \mathrm{pH} 7.4,1 \mathrm{mM}$ EDTA, $150 \mathrm{mM} \mathrm{NaCl}$ and Complete Protease Inhibitor (Roche)) and incubated on ice for 10 min before collection. Cell debris was pelleted and equal volumes of supernatant collected. $100 \mu \mathrm{L}$ of the supernatant was kept as input and $60 \mu \mathrm{L}$ of monoclonal Anti-HA-agarose (Clone HA-7, Sigma-Aldrich) was added to the remainder of the supernatant which was incubated on a rotating wheel at $4{ }^{\circ} \mathrm{C}$ overnight. The agarose was washed three times with lysis buffer and resuspended in $50 \mu \mathrm{L}$ of $2 \times$ SDS-sample buffer.

For immunoprecipitation of Fas receptor complexes (DISC) by protein G, HeLa cells were grown in $10 \mathrm{~cm}$ tissue culture dishes and infected with various EPEC derivatives for $2 \mathrm{~h}$. 
Cells were then treated with $50 \mu \mathrm{g} / \mathrm{mL}$ gentamycin and $1 \mu \mathrm{g}$ of Fc $\gamma$-FasL for $1 \mathrm{~h}$. An uninfected control was left untreated. Cells were lysed in $400 \mu \mathrm{L}$ of $2 \times$ DISC lysis buffer (20 mM Tris-HCl pH 7.4, $150 \mathrm{mM} \mathrm{NaCl}, 2$ mM EDTA, 1\% TritonX-100, 10\% glycerol, and Complete Protease Inhibitor (Roche)) and incubated on ice for $10 \mathrm{~min}$ prior to centrifugation to remove cell debris. An aliquot ( $80 \mu \mathrm{L}$ ) of the supernatant was kept as input and $40 \mu \mathrm{L}$ of Protein G Dynabeads (Invitrogen) was added to the remainder of the sample which was placed on a rotating wheel at $4^{\circ} \mathrm{C}$ overnight. Beads were washed three times with lysis buffer and finally resuspended in $75 \mu \mathrm{L}$ of DISC lysis buffer with $25 \mu \mathrm{L}$ of $5 \times$ SDS-sample buffer.

All samples were boiled for $5 \mathrm{~min}$, subjected to SDS-PAGE and transferred to nitrocellulose membranes. Membranes were probed with the following primary antibodies where necessary: mouse monoclonal anti-HA.11 (16B12) (Covance, USA), mouse monoclonal anti-FLAG M2-HRP (Sigma-Aldrich), mouse monoclonal anti-FADD (BD Transduction Laboratories), rabbit monoclonal anti-Fas (C18C12) (Cell Signalling), rabbit polyclonal anti-caspase-8 (D35G2) (Cell Signalling), mouse monoclonal anti-GFP (7.1 and 13.1) (Roche) or mouse monoclonal anti- $\beta$-actin (AC-15) diluted 1:1000 in TBS with 5\% BSA and $0.1 \%$ Tween. Detection and visualization were performed as previously mentioned.

\section{Preparation of GST and His tagged proteins, demonstration of GIcNAcylation of recombinant FADD by NleB1 and detection by immunoblotting}

Overnight cultures of BL21 (pGEX-4T-1), BL21 (pGEX-NleB1), BL21 (pGEX-NleB1 ${ }_{\text {AAA }}$ ) and BL21 (pET-FADD), BL21 (pET-FADD ${ }_{\mathrm{R} 117 \mathrm{~A}}$ ), BL21 (pET-FADD ${ }_{\mathrm{S} 122 \mathrm{~A}}$ ) grown in LB were diluted 1:100 in $200 \mathrm{~mL}$ of LB supplemented with either kanamycin (pET) or ampicillin (pGEX) $(100 \mathrm{mg} / \mathrm{mL})$ with shaking to an optical density of $\left(A_{600}\right) 0.6$ at $37^{\circ} \mathrm{C}$. Cells were incubated with $1 \mathrm{mM}$ IPTG and grown for a further $2 \mathrm{~h}$ then pelleted by centrifugation. Proteins were purified by either nickel or glutathione affinity chromatography in accordance with the manufacturer's instructions (Novagen, EMD4Biosciences, USA). Protein concentrations were determined using a BCA kit (Thermo Scientific).

For detection of GlcNAcylation of FADD by NleB1, $2 \mu \mathrm{g}$ of purified recombinant proteins were incubated either alone or in combination at $37^{\circ} \mathrm{C}$ for $4 \mathrm{~h}$ in the presence of $1 \mathrm{mM}$ UDPGlcNAc. $5 \times$ SDS sample buffer was added to the samples before boiling for $5 \mathrm{~min}$. Samples were subjected to SDS-PAGE and transferred to nitrocellulose membranes which were subsequently probed with the following primary antibodies: mouse monoclonal anti-GlcNAc (CTD110.6) (Cell Signalling), which recognises O-linked and N-linked GlcNAc ${ }^{24}$, rabbit polyclonal anti-GST (Cell, Signalling), or mouse monoclonal anti-His (AD1.1.10) (AbD Serotech) diluted 1:1000 in TBS with 5\% BSA and 0.1\% Tween. Detection and visualization were performed as previously mentioned. Detection of GlcNAcylated recombinant FADD was performed as three technical replicates.

For detection of GlcNAcylation during transient transfection with NleB1 and FADD, HEK293T cells were grown in $10 \mathrm{~cm}$ tissue culture dishes (Greiner Bio One) and cotransfected with GFP-NleB1 or GFP-NleB1 ${ }_{\mathrm{AAA}}$ in combination with FADD-FLAG. Cells were washed three times with cold PBS and lysed in $600 \mu \mathrm{L}$ of cold lysis buffer (1\% Triton 
$\mathrm{X}-100,50 \mathrm{mM}$ Tris-HCl pH 7.4, $1 \mathrm{mM}$ EDTA, $150 \mathrm{mM} \mathrm{NaCl}$ and Complete Protease Inhibitor (Roche)) and incubated on ice for $10 \mathrm{~min}$ before collection. Cell debris was pelleted and equal volumes of supernatant collected. $80 \mu \mathrm{L}$ of the supernatant was kept as input and $40 \mu \mathrm{L}$ of monoclonal anti-FLAG M2 magnetic beads (Sigma-Aldrich) was added to the remainder of the supernatant which was incubated on a rotating wheel at $4{ }^{\circ} \mathrm{C}$ overnight. The beads were washed three times with cold lysis buffer followed by elution of bound proteins with $80 \mu \mathrm{g}$ of FLAG peptide (Sigma-Aldrich) to which $16 \mu \mathrm{L}$ of $5 \times$ SDS sample buffer was added. Samples were boiled for $5 \mathrm{~min}$, subjected to SDS-PAGE and transferred to nitrocellulose membranes. Membranes were probed with the following primary antibodies where necessary: mouse monoclonal anti-O/N-GlcNAc (CTD110.6) (Cell Signalling), mouse monoclonal anti-FLAG M2-HRP (Sigma-Aldrich), mouse monoclonal anti-GFP (7.1 and 13.1) (Roche) or mouse monoclonal anti- $\beta$-actin (AC-15) diluted 1:1000 in TBS with 5\% BSA and 0.1\% Tween. Detection and visualization were performed as previously mentioned.

\section{Glyco-site specific analysis of FADD}

Intact protein analysis was performed by the Proteomics Laboratory at the Walter and Eliza Hall Institute (Fig. 2B and Supp Fig. S7). $10 \mu \mathrm{g}$ of intact recombinant His-FADD, HisFADD $_{\mathrm{R} 117 \mathrm{~A}}$ or HisFADD ${ }_{\mathrm{S} 122 \mathrm{~A}}$ incubated with GST-NleB1 and UDP-GlcNAc, was injected and separated by nano-flow reversed-phase liquid chromatography on a nano LC system (1200 series, Agilent, USA) using a custom packed C4 capillary column $(15 \mathrm{~cm} \times 0.15 \mathrm{~mm}$

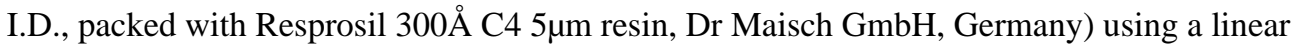
45 min gradient from 5 to $100 \%$ buffer B at a flow rate of $1.2 \mathrm{ul} / \mathrm{min}$ (A: $0.1 \%$ Formic acid in Milli-Q water B: $0.1 \%$ Formic acid, $80 \%$ acetonitrile, (Mallinckrodt Baker, New Jersey, USA) 20\% Milli-Q water). The nano HPLC was coupled on-line to a Q-Exactive mass spectrometer equipped with a nano-electrospray ion source (ThermoFisher Scientific) set to acquire full scan and all-ion-fragmentation (AIF) sequentially. Mass accuracy of the intact protein was achieved by summing multiple lower resolution $(35,000)$ full scan MS events. The intact mass and error calculation was facilitated by the open source program mMass.

Tryptic peptide analysis was performed by the Proteomics Laboratory at the Walter and Eliza Hall Institute (Fig. 2C, Supp Fig. S5). Reacted and unreacted mixtures of recombinant FADD and NleB1 were purified by SDS-PAGE and bands corresponding to FADD were excised and manual in-gel reduction, alkylation, and tryptic digestion was performed. Extracted peptides were injected and separated by nano flow reversed-phase liquid chromatography on a nano LC system (1200 series, Agilent, USA) using a nanoAcquity C18 $150 \mathrm{~mm} \times 0.15 \mathrm{~mm}$ I.D. column (Waters, USA) with a linear 45-min gradient from 5 to $100 \%$ buffer B set at a flow rate of $1.2 \mu \mathrm{l} / \mathrm{min}$ (A: $0.1 \%$ Formic acid in Milli-Q water, B: 0.1\% Formic acid, 80\% acetonitrile, (Mallinckrodt Baker, New Jersey, USA) 20\% Milli-Q water). The nano HPLC was coupled on-line to an LTQ-Orbitrap XL mass spectrometer equipped with a nano-electrospray ion source (ThermoFisher Scientific) for automated MS/MS using multi-stage activation (MSA) setting. The Orbitrap was run in a datadependent acquisition mode with the Orbitrap resolution set at 30,000 and the top-three multiply charged species selected for fragmentation in the linear ion trap by collisioninduced dissociation (CID) (single charged species were ignored). Fragment ions where 
analysed on the orbitrap with the resolution set at 7, 500 with the ion threshold set to 15,000 counts. The activation time was set to $30 \mathrm{~ms}$, normalized collision energy set to 35 . Raw files consisting of full-scan MS and high resolution MS/MS spectra were converted to the MGF data format with Proteome Discoverer 1.4 and searched against UniProt database (2013/02) limiting the search to mouse taxonomy and custom FASTA database containing the protein constructs of FADD and NleB using Mascot v2.4. Mascot parameters for each search included Trypsin/no P enzyme with six missed cleavages, a fixed modification in the form of carbamidomethyl at Cys residues and variable modification of HexNAc at Ser/Thr/Asn/Arg residues, Acetyl at protein N-Terminal, oxidation at Met residues. Spectra were searched with a mass tolerance of $20 \mathrm{ppm}$ in MS mode and $40 \mathrm{mmu}$ in MS/MS mode. The MS/MS fragmentation of modified peptides obtained from the Mascot search was manually sequenced using mMass to assign ion peaks and confirm the site of modification. Detection of GlcNAcylated recombinant FADD by mass spectrometry was performed as two technical replicates.

The site of modification was verified independently using ETD fragmentation on an Orbitrap Elite mass spectrometer by the Bio21 Mass Spectrometry and Proteomics Facility at the University of Melbourne (Extended Data Fig. 3). The protein complex was digested with Endoproteinase AspN (Roche) at enzyme to protein ratio of $1: 5$ at $37^{\circ} \mathrm{C}$ overnight. Reaction contained FADD, NleB1 and UDP-GlcNAc and the incubation was performed as described earlier for anti-GlcNAc immunoblot analysis. LC-MS/MS was carried out on a LTQ Orbitrap Elite (Thermo Scientific) with an EASY nano electrospray interface coupled to an Ultimate 3000 RSLC nanosystem (Dionex). The nanoLC system was equipped with a Acclaim Pepmap nano-trap column (Dionex - C18, $100 \AA, 75 \mu \mathrm{m} \times 2 \mathrm{~cm}$ ) and a Thermo EASY-Spray column (Pepmap RSLC C18, $2 \mu \mathrm{m}, 100 \AA, 75 \mu \mathrm{m} \times 25 \mathrm{~cm}$ ). $4 \mu \mathrm{l}$ of the peptide mix was loaded onto the enrichment (trap) column at an isocratic flow of $4 \mu \mathrm{l} / \mathrm{min}$ of $3 \%$ $\mathrm{CH}_{3} \mathrm{CN}$ containing $0.1 \%$ formic acid for 5 min before the enrichment column is switched inline with the analytical column. The eluents used for the liquid chromatography were $0.1 \%$ (v/v) formic acid (solvent $\mathrm{A}$ ) and $100 \% \mathrm{CH}_{3} \mathrm{CN} / 0.1 \%$ formic acid (v/v). $0.1 \%$ formic acid $(\mathrm{v} / \mathrm{v})$. The flow following gradient was used: $3 \% \mathrm{~B}$ to $12 \% \mathrm{~B}$ for $1 \mathrm{~min}, 12 \% \mathrm{~B}$ to $35 \% \mathrm{~B}$ in $20 \mathrm{~min}, 35 \% \mathrm{~B}$ to $80 \% \mathrm{~B}$ in $2 \mathrm{~min}$ and maintained at $80 \%$ B for $2 \mathrm{~min}$ and equilibration at $3 \% \mathrm{~B}$ for $7 \mathrm{~min}$ before the next sample injection. The LTQ Orbitrap Elite mass spectrometer was operated in the data dependent mode with nano ESI spray voltage of $+2.0 \mathrm{kv}$, capillary temperature of $250^{\circ} \mathrm{C}$ and S-lens RF value of $60 \%$. A sequential mode whereby spectra were acquired first in positive mode with full scan scanning from m/z 300-1650 in the FT mode at 120,000 resolution followed by Collision induced dissociation (CID), Electron transfer dissociation (ETD) and High energy collision dissociation (HCD). CID in the linear ion trap was carried out in parallel with three most intense peptide ions with charge states $\geq 2$ isolated and fragmented using normalized collision energy of 35 and activation $Q$ of 0.25 . The decision tree procedure for ETD activation was also applied whereby peptides with charge state 3 of $<650 \mathrm{~m} / \mathrm{z}$, charge state 4 of $<900 \mathrm{~m} / \mathrm{z}$ and charge state 5 of $<1000 \mathrm{~m} / \mathrm{z}$ were subjected to $100 \mathrm{~ms}$ of ETD activation. HCD at 15,000 resolution using normalized collision energy of 35 and $0.1 \mathrm{~ms}$ activation time was carried out on every precursor selected. The mass spectra were searched against the Uniprot database using the Sequest HT (V1.3) search algorithm as part of the Proteome Discoverer 1.4 Workflow (Thermo Scientific). Searching 
parameters used were: variable modifications (HexNAc of N, S, T and R; 203.079), 2 missed tryptic cleavages, $10 \mathrm{ppm}$ peptide mass tolerance and 0.6 Da fragment ion mass tolerance. The false-discovery rate (derived from corresponding decoy database search) was less than $1 \%$. Peptides of interest were manually inspected and validated.

\section{IL-8 secretion assay}

For analysis of IL-8 secretion, HeLa cell monolayers were infected for $3 \mathrm{~h}$ before being incubated for 8-12 h in media supplemented with $50 \mu \mathrm{g} / \mathrm{mL}$ gentamycin with or without 20 ng/mL TNF (Calbiochem, EMD4Biosciences, USA). Following this, the HeLa cell supernatant was collected and either used immediately or stored at $-20^{\circ} \mathrm{C}$ for subsequent analysis of IL-8 secretion. IL-8 secretion was measured using the Quantikine Human IL-8 Immunoassay (R\&D Systems, MN) according to the manufacturer's instructions. Samples were measured on a FLUOstar Omega microplate reader (BMG Labtech, Germany). Differences in IL-8 secretion were assessed for significance by one-way analysis of variance (ANOVA) with Dunnett's Multiple Comparison post-test. Data are from at least three biological replicates performed in triplicate.

\section{Detection of cleaved caspase-8 by immunoblotting}

For detection of cleaved caspase-8 during EPEC infection, HeLa cells were grown in 24 well tissue culture plates (Greiner Bio One, Germany) and infected for $3 \mathrm{~h}$ with various EPEC derivatives. Cells were then treated with $50 \mathrm{ug} / \mathrm{ml}$ gentamicin, and either $20 \mathrm{ng} / \mathrm{ml}$ of Fc $\gamma$-FasL, $20 \mathrm{ng} / \mathrm{ml} \mathrm{TNF}$, or a combination of $20 \mathrm{ng} / \mathrm{ml} \mathrm{TNF}$ and $10 \mathrm{ug} / \mathrm{ml}$ cycloheximide (CHX) for a further $60 \mathrm{~min}$ and lysed in $60 \mathrm{ul}$ of $2 \times$ SDS-sample buffer. For detection of cleaved caspase- 8 by transfection, HeLa cells were grown in 24 well tissue culture plates and either left untransfected or transfected with GFP, GFP-NleB1 or GFP-NleB $1_{\text {AAA }}$ for 18-24 h using FuGENE® 6 (Roche, Germany). Cells were then treated with $20 \mathrm{ng} / \mathrm{mL}$ of Fc $\gamma$-FasL for a further $60 \mathrm{~min}$ and collected by lysis in $60 \mu \mathrm{L}$ of $2 \times \mathrm{SDS}$-sample buffer. All samples were boiled for $5 \mathrm{~min}$ and subjected to SDS-PAGE followed by transfer to nitrocellulose membranes (PALL, USA). Membranes were incubated at least overnight at $4^{\circ} \mathrm{C}$ with rabbit polyclonal anti-cleaved caspase-8 (Asp391) (18C8) (Cell Signaling) diluted 1:1000 in TBS with 5\% skim milk and $0.1 \%$ Tween (Sigma-Aldrich, MO, USA), rabbit polyclonal anti-caspase-8 (D35G2) (Cell Signaling) diluted 1:1000 or mouse monoclonal anti- $\beta$-actin (AC-15) (Sigma-Aldrich) diluted 1:5000 in TBS with 5\% BSA (Sigma-Aldrich) and $0.1 \%$ Tween. Proteins were detected using anti-rabbit or anti-mouse IgG secondary antibodies conjugated to horseradish peroxidase (PerkinElmer, USA) and developed with either ECL Western blotting reagent (Amersham, USA) or Western Lightning Ultra reagent (PerkinElmer). All secondary antibodies were diluted 1:3000 in TBS with 5\% BSA and $0.1 \%$ Tween. Images were visualized using an MFChemiBis imaging station (DNR, Isreal). At least three biological replicates were performed for all experiments.

\section{Detection of cleaved caspase-8 and -3 in vitro by immunofluorescence microscopy}

For visualization of caspase- 8 cleavage by immunofluorescence microscopy, HeLa cells were either infected with EPEC E2348/69 derivatives for $3 \mathrm{~h}$ or transfected for $16 \mathrm{~h}$ followed by an additional $1 \mathrm{~h}$ of treatment with $20 \mathrm{ng} / \mathrm{mL} \mathrm{Fc} \gamma$-FasL. One experiment used 
recombinant rhFasL to treat transfected HeLa cells for comparison with tunicamycin treatment (Extended Data Fig. 1d, e). For this, HeLa cells were transfected for $16 \mathrm{~h}$ and treated with $200 \mathrm{ng} / \mathrm{mL}$ of rhFasL (R\&D Systems, Minneapolis, USA). For visualization of caspase- 3 cleavage induced by tunicamycin, HeLa cells were transfected for $16 \mathrm{~h}$, followed by $18 \mathrm{~h}$ treatment with $5 \mu \mathrm{g} / \mathrm{mL}$ tunicamycin (Sigma-Aldrich). Cells were then fixed in $3.7 \%$ (wt/vol) formaldehyde (Sigma-Aldrich) in PBS for $10 \mathrm{~min}$ and permeabilized with $0.2 \%$ Triton (Sigma-Aldrich) for $4 \mathrm{~min}$. Following 30 min blocking in PBS with 3\% (wt/vol) BSA, samples were exposed to primary antibodies (specific to cleaved caspase- 8 or cleaved caspase-3; Cell Signaling Technology) diluted in blocking solution for $1 \mathrm{~h}$ at $20^{\circ} \mathrm{C}$, except for cleaved caspase-3, which was incubated overnight at $4^{\circ} \mathrm{C}$. For fluorescent actin staining in EPEC infected cells, $0.5 \mu \mathrm{g} / \mathrm{mL}$ of phalloidin conjugated to rhodamine (Sigma-Aldrich) was added during primary antibody incubation. 4', 6-diamidino-2-phenylindole (DAPI; Invitrogen) was applied at $0.5 \mu \mathrm{g} / \mathrm{mL}$ in blocking solution for $5 \mathrm{~min}$ at $20^{\circ} \mathrm{C}$ post secondary antibody treatment. Secondary antibodies were all coupled to Alexa Fluor® dyes (Invitrogen, USA) applied to cells at 1:2000 in blocking solution for $1 \mathrm{~h}$ at $20^{\circ} \mathrm{C}$. Coverslips were mounted onto microscope slides with Prolong Gold anti-fade reagent (Invitrogen). Images were acquired using a Zeiss confocal laser scanning microscope with a $100 \times / \mathrm{EC}$ Epiplan-Apochromat oil immersion objective. Cleavage of caspase-8 or caspase-3 was quantified from at least three biological replicates performed in duplicate for both transfection and infection studies counting at least 100 cells per field.

\section{Cell viability assays (MTT and propidium iodide staining)}

HeLa cells were transfected in 24 well tissue culture plates for 18-24 h before being left untreated or treated with $20 \mathrm{ng} / \mathrm{mL}$ of Fc $\gamma$-FasL for a further $60 \mathrm{~min}$. The cells were washed once with PBS and replaced with DMEM containing $0.1 \mu \mathrm{g} / \mathrm{ml} 3$-(4,5-Dimethylthiazol-2yl)-2,5-diphenyltetrazolium bromide (MTT) (Sigma) for $1 \mathrm{~h}$, after which the medium was removed and $100 \mu \mathrm{L}$ of dimethyl-sulfoxide (DMSO; Sigma) was added to each well. After thorough mixing on an orbital shaker for $1 \mathrm{~min}$, the absorbance at $540 \mathrm{~nm}$ for each well was obtained using a FLUOstar Omega microplate reader (BMG Labtech, Germany). Results were obtained from at least three biological replicates performed in triplicate.

For analysis of cell viability by PI staining, HeLa cell monolayers were infected for $3 \mathrm{~h}$ before being incubated for $1 \mathrm{~h}$ in media supplemented with $50 \mu \mathrm{g} / \mathrm{mL}$ gentamycin with 20 $\mathrm{ng} / \mathrm{mL} \mathrm{Fc} \gamma$-FasL. Propidium iodide $(50 \mu \mathrm{g} / \mathrm{ml})$ was added for the final $15 \mathrm{~min}$ of treatment. Cells were fixed and stained for confocal microscopy as previously mentioned. Phalloidin conjugated to FITC (Sigma-Aldrich) was used at $0.5 \mu \mathrm{g} / \mathrm{mL}$ to stain for actin. Duplicate coverslips were counted for PI positive cells, and results were obtained from at least three biological replicates counting at least 100 cells per field.

\section{Animal experiments}

All animal experimentation was approved by the University of Melbourne Animal Ethics Committee, applications 0808209 and 1112062. All genetically modified and spontaneous mutant mice are on a C57BL/6 background. Overnight cultures of bacterial strains were pelleted by centrifugation and resuspended in PBS. C57BL/6 (WT), Fas ${ }^{l p r / p r}$, Fas ${ }^{g l d} /$ gld and $\mathrm{Bid}^{-/-}$mutant mice (6 to 8 weeks old, male and female mice) were inoculated by oral 
gavage with $200 \mu \mathrm{L}$ containing approximately $1 \times 10^{9} \mathrm{CFU}$ of $C$. rodentium, or a lower dose of $1 \times 10^{8} \mathrm{CFU}$ when testing for in prolonged infection (up to 33 days). The viable count of the inoculum was determined retrospectively by plating dilutions of the inoculum on plates with appropriate antibiotics. Animals were allocated to experimental groups to ensure even distribution of age, sex and weight. Investigators were not blinded to group allocation.

Sample size was at least five animals per group for statistical power per biological replicate. Larger sample sizes (up to 12 mice per group) were used where mice were available. Infection experiments were repeated at least twice regardless of sample size to ensure reproducibility and results represent all experimental data combined from repeated infections. Mice were weighed every 2 days and faeces collected every 2 or 4 days for enumeration of CFU. The viable bacterial count per $100 \mathrm{mg}$ of faeces was determined by plating serial dilutions in duplicate of faeces onto medium containing selective antibiotics.

\section{Histological analysis and scoring of tissue pathology and diarrhoea}

The increased intestinal pathology observed in CR-infected FAS-, FasL- and Bid-deficient mice revealed a function for the FAS apoptotic pathway in limiting the extent of colitis during gastrointestinal infection. This exacerbated disease compared to CR infection of WT mice likely arose from the difference between a complete block of FAS signalling in the gut epithelium of FAS-deficient mice as opposed to less complete inhibition of FAS signalling in the gut epithelium by NleB in WT mice, which depends on the timing and efficiency of $\mathrm{CR}$ attachment and NleB translocation. A grading system for diarrhoea was developed where a score of diarrhoea severity from $0-4$ was recorded every 4 days. The scoring system can be interpreted as follows; 0 (no diarrhoea): solid stool with no sign of soiling around the anus. The stool is very firm when subjected to pressure with tweezers, 1 (very mild diarrhoea): formed stools that appear moist on the outside, and no sign of soiling around the anus. Stool is less firm when considerable pressure applied with tweezers, 2 (mild diarrhoea): formed stools that appear moist on the outside, and some signs of soiling around anus. Stools will easily submit to pressure applied with tweezers, 3 (diarrhoea): no formed stools with a mucous-like appearance. Considerable soiling around the anus and the fur around tail. Mouse takes a long time to pass stool, 4 (severe, watery diarrhoea): mostly clear or mucous-like liquid stool with very minimal solid present and considerable soiling around anus. Mouse may not be able to pass stool at all and may have a hunched appearance.

Occasionally, blood may be observed in the stool.

For histological analysis, mice inoculated with the higher dose of C. rodentium $\left(1 \times 10^{9}\right.$ $\mathrm{CFU}$ ) were culled at day 10 or 12 post-infection and the distal portion of colon from the cecum to the rectum removed aseptically and weighed after removal of faecal pellets. Colons and spleens were homogenized mechanically in PBS using a Seward 80 stomacher, and the bacterial CFU per $100 \mathrm{mg}$ of organ homogenate was enumerated by plating onto LB containing the appropriate antibiotics. Colons from a representative group of these mice were collected and fixed in $4 \%(\mathrm{wt} / \mathrm{vol})$ paraformaldehyde (Sigma-Aldrich) and sectioned for H\&E staining and assessment of gut pathology. A scoring system (0-3) was used by a veterinary pathologist to assess the extent of tissue damage: $0=$ no damage, $1=$ discrete lesion, $2=$ mucosal erosion, $3=$ extensive mucosal damage/ulceration (extending into muscularis and deeper). 


\section{Detection of $C$. rodentium and cleaved caspase-8 in mouse colon tissue by immunofluorescence microscopy}

For immunofluorescence staining of mouse colons, the distal portion of colon from the caecum to the rectum was removed from representative groups of infected and uninfected C57BL/6 (WT) and Fas ${ }^{l p r / p r}$ mice, gently flushed with a 1:1 mix of OCT ${ }^{\mathrm{TM}}$ compound (Tissue-Tek ${ }^{\circledR}$ ) and PBS and frozen at $-80^{\circ} \mathrm{C}$ in full strength OCT ${ }^{\mathrm{TM}}$ compound. $10 \mu \mathrm{m}$ sections were cut on a Leica CM3050S cryostat and mounted onto Menzel-Gläser Superfrost ${ }^{\circledR}$ Plus slides (Thermo Fisher Scientific). Slide sections were dried for at least $2 \mathrm{~h}$ before fixing in absolute acetone at $-20^{\circ} \mathrm{C}$, followed by a 30 min block with Dako ProteinFree Block Serum (Dako). Sections were incubated with primary antibody; polyclonal rabbit anti-C. rodentium O152 (Statens Serum Institute, Copenhagen) diluted 1:100 or mouse specific monoclonal rabbit anti-cleaved caspase-8 (Asp387) (D5B2) XP® diluted 1:500 in $2.5 \%$ normal donkey serum (NDS) (Jackson Immunoresearch Laboratories Inc.) in PBS. Secondary antibody coupled to Alexa Fluor®-488 was applied at 1:1000 in 2.5\% NDS followed by 2 min of exposure to Hoechst 33258 (Invitrogen) diluted at 1:2000 in 2.5\% NDS. Slides were mounted with glass coverslips using Prolong Gold anti-fade reagent (Invitrogen) and images were acquired using a Zeiss LSM700 inverted Axio Observer with LED laser lines at $405 \mathrm{~nm}$ and $488 \mathrm{~nm}$, and a Plan-Apochromat 20×/0.8 objective. To determine the average depth of penetration by $C$. rodentium in mouse intestinal crypts, Image $\mathbf{J}$ was used to measure the distance of bacterial staining from the epithelial surface on immunofluorescent images. Results are from five independent sections with at least three measurements taken from each section. To quantify the amount of cleaved caspase- 8 in infected mouse colons, the relative fluorescence intensity of cleaved caspase- 8 staining was expressed as a percentage of the relative fluorescence intensity of Hoechst staining from 5 independent infected fields of 3 mice for each bacterial strain.

Hyperplasia of colonic crypts (crypt height) was measured using MIRAX software on H\&E stained sections at day 10 and 12 post-infection. Data are from 4 sections of distal colon measured at least $50 \mu \mathrm{m}$ apart per animal from at least three individual mice per group.

\section{Statistical analysis}

All statistical analyses were performed using GraphPad Prism version 6.0. Statistical tests used were unpaired two-tailed Student's $t$-test for pairwise comparisons between groups or One-way ANOVA with Dunnett's Multiple Comparison Test for multiple comparisons where indicated. Variance was similar in all comparisons. Differences in faecal counts of $\mathrm{CR}$ from mice and diarrhoea scores were assessed using a Mann Whitney $\mathrm{U}$ test, where normal distribution was not assumed. $P<0.05$ was considered to be significant.

\section{Supplementary Material}

Refer to Web version on PubMed Central for supplementary material.

\section{Acknowledgments}

We gratefully acknowledge Philippe Bouillet for the gift of $\mathrm{Bid}^{-/}$mice and Thomas Cumming for assistance with animal work. This work was supported by the Australian National Health and Medical Research Council (Program 
Grant \#606788 to E.L.H., Project Grants \#637332, \#1009145 to A.S., \#1009145 to L.O.R., Australia Fellowship to A.S.), the Wellcome Trust to GF, the Juvenile Diabetes Foundation; the Leukaemi a and the Lymphoma Society (New York; SCOR grant \#7413) to AS. E.L.H was supported by an Australian Research Council Future Fellowship. J.S.P, M.K., T.W., C.G. and P.R. were supported by Australian Postgraduate Awards. This work was made possible through Victorian State Government Operational Infrastructure Support and Australian Government NHMRC IRIISS.

\section{References}

1. Wong AR, et al. Enteropathogenic and enterohaemorrhagic Escherichia coli: even more subversive elements. Mol Microbiol. 2011; 80:1420-1438. [PubMed: 21488979]

2. Srikanth CV, Mercado-Lubo R, Hallstrom K, McCormick BA. Salmonella effector proteins and host-cell responses. Cell Mol Life Sci. 2011; 68:3687-3697. [PubMed: 21984608]

3. Ashida H, et al. Shigella deploy multiple countermeasures against host innate immune responses. Curr Opin Microbiol. 2011; 14:16-23. [PubMed: 20934372]

4. Park HH, et al. The death domain superfamily in intracellular signaling of apoptosis and inflammation. Annu Rev Immunol. 2007; 25:561-586. [PubMed: 17201679]

5. Strasser A, Jost PJ, Nagata S. The many roles of FAS receptor signaling in the immune system. Immunity. 2009; 30:180-192. [PubMed: 19239902]

6. Schneider-Brachert W, et al. Compartmentalization of TNF receptor 1 signaling: internalized TNF receptosomes as death signaling vesicles. Immunity. 2004; 21:415-428. [PubMed: 15357952]

7. Micheau O, Tschopp J. Induction of TNF receptor I-mediated apoptosis via two sequential signaling complexes. Cell. 2003; 114:181-190. [PubMed: 12887920]

8. Newton HJ, et al. The type III effectors NleE and NleB from enteropathogenic E. coli and OspZ from Shigella block nuclear translocation of NF-kappaB p65. PLoS Pathog. 2010; 6:e1000898. [PubMed: 20485572]

9. Zhang L, et al. Cysteine methylation disrupts ubiquitin-chain sensing in NF-kappaB activation. Nature. 2012; 481:204-208. [PubMed: 22158122]

10. Gao X, et al. NleB, a bacterial effector with glycosyltransferase activity, targets GAPDH function to inhibit NF-kappaB activation. Cell Host Microbe. 2013; 13:87-99. [PubMed: 23332158]

11. Imtiyaz HZ, Zhang Y, Zhang J. Structural requirements for signal-induced target binding of FADD determined by functional reconstitution of FADD deficiency. J Biol Chem. 2005; 280:3136031367. [PubMed: 16009710]

12. Wang L, et al. The Fas-FADD death domain complex structure reveals the basis of DISC assembly and disease mutations. Nat Struct Mol Biol. 2010; 17:1324-1329. [PubMed: 20935634]

13. Strasser A, Harris AW, Huang DC, Krammer PH, Cory S. Bcl-2 and Fas/APO-1 regulate distinct pathways to lymphocyte apoptosis. EMBO J. 1995; 14:6136-6147. [PubMed: 8557033]

14. Kelly M, et al. Essential role of the type III secretion system effector NleB in colonization of mice by Citrobacter rodentium. Infect Immun. 2006; 74:2328-2337. [PubMed: 16552063]

15. Jost PJ, et al. XIAP discriminates between type I and type II FAS-induced apoptosis. Nature. 2009; 460:1035-1039. [PubMed: 19626005]

16. Kaufmann T, et al. The BH3-only protein bid is dispensable for DNA damage- and replicative stress-induced apoptosis or cell-cycle arrest. Cell. 2007; 129:423-433. [PubMed: 17448999]

17. Mundy R, et al. Identification of a novel Citrobacter rodentium type III secreted protein, EspI, and roles of this and other secreted proteins in infection. Infect Immun. 2004; 72:2288-2302. [PubMed: 15039354]

18. Deng W, et al. Dissecting virulence: systematic and functional analyses of a pathogenicity island. Proc Natl Acad Sci U S A. 2004; 101:3597-3602. [PubMed: 14988506]

19. Wickham ME, Brown NF, Boyle EC, Coombes BK, Finlay BB. Virulence is positively selected by transmission success between mammalian hosts. Curr Biol. 2007; 17:783-788. [PubMed: 17442572]

20. Wickham ME, et al. Bacterial genetic determinants of non-O157 STEC outbreaks and hemolyticuremic syndrome after infection. J Infectious Dis. 2006; 194:819-827. [PubMed: 16941350] 
21. Karmali MA, et al. Association of genomic O island 122 of Escherichia coli EDL 933 with verocytotoxin-producing Escherichia coli seropathotypes that are linked to epidemic and/or serious disease. J Clin Microbiol. 2003; 41:4930-4940. [PubMed: 14605120]

22. Jostins L, et al. Host-microbe interactions have shaped the genetic architecture of inflammatory bowel disease. Nature. 2012; 491:119-124. [PubMed: 23128233]

23. Datsenko KA, Wanner BL. One-step inactivation of chromosomal genes in Escherichia coli K-12 using PCR products. Proc Natl Acad Sci U S A. 2000; 97:6640-6645. [PubMed: 10829079]

24. Isono T. O-GlcNAc-specific antibody CTD110.6 cross-reacts with N-GlcNAc2-modified proteins induced under glucose deprivation. PLoS One. 2011; 6:e18959. [PubMed: 21526146]

25. Levine MM, et al. Escherichia coli strains that cause diarrhoea but do not produce heat-labile or heat-stable enterotoxins and are non-invasive. Lancet. 1978; 1:1119-1122. [PubMed: 77415]

26. Perna NT, et al. Genome sequence of enterohaemorrhagic Escherichia coli O157:H7. Nature. 2001; 409:529-533. [PubMed: 11206551]

27. Zurawski DV, et al. The NleE/OspZ family of effector proteins is required for polymorphonuclear transepithelial migration, a characteristic shared by enteropathogenic Escherichia coli and Shigella flexneri infections. Infect Immun. 2008; 76:369-379. [PubMed: 17984206]

28. Garmendia J, et al. TccP is an enterohaemorrhagic Escherichia coli O157:H7 type III effector protein that couples Tir to the actin-cytoskeleton. Cell Microbiol. 2004; 6:1167-1183. [PubMed: 15527496]

29. Mundy R, et al. Identification of a novel type IV pilus gene cluster required for gastrointestinal colonization of Citrobacter rodentium. Mol Microbiol. 48:795-809. [PubMed: 12694622] 
a

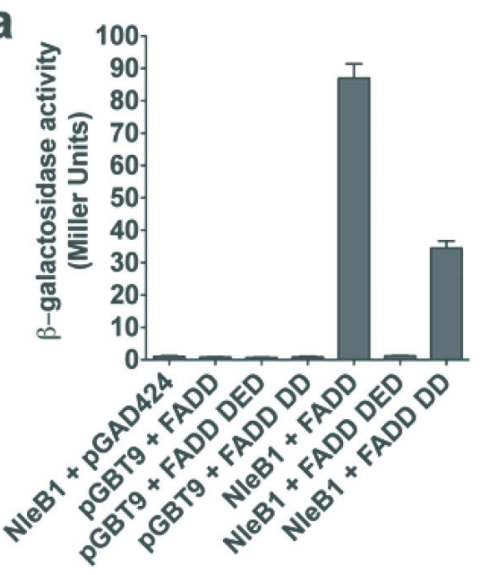

d

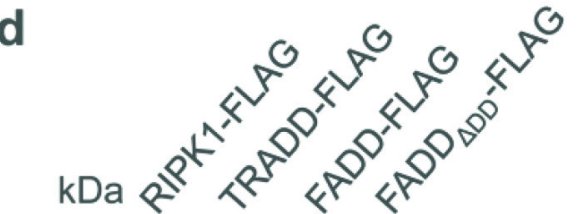

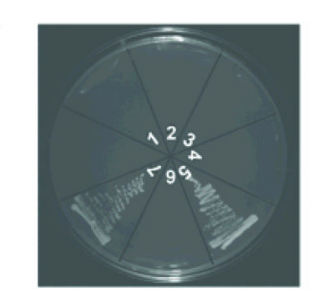

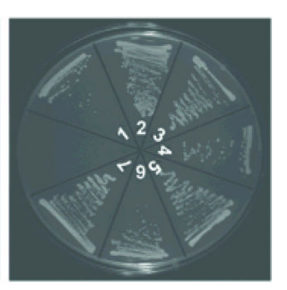

1. $p G A D 424+\mathrm{NleB} 1$

2. $\mathrm{pGBT} 9+\mathrm{FADD}$

3. PGBT9 + FADD DED

4. $\mathrm{pGBT9}+$ FADD DD

5. NleB1 + FADD

6. NleB1 + FADD DED

7. NleB1 + FADD DD
C

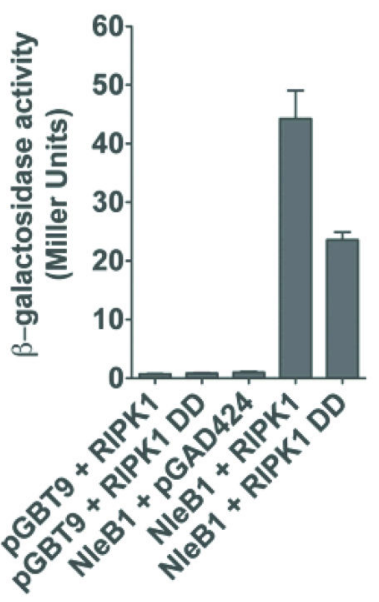

e
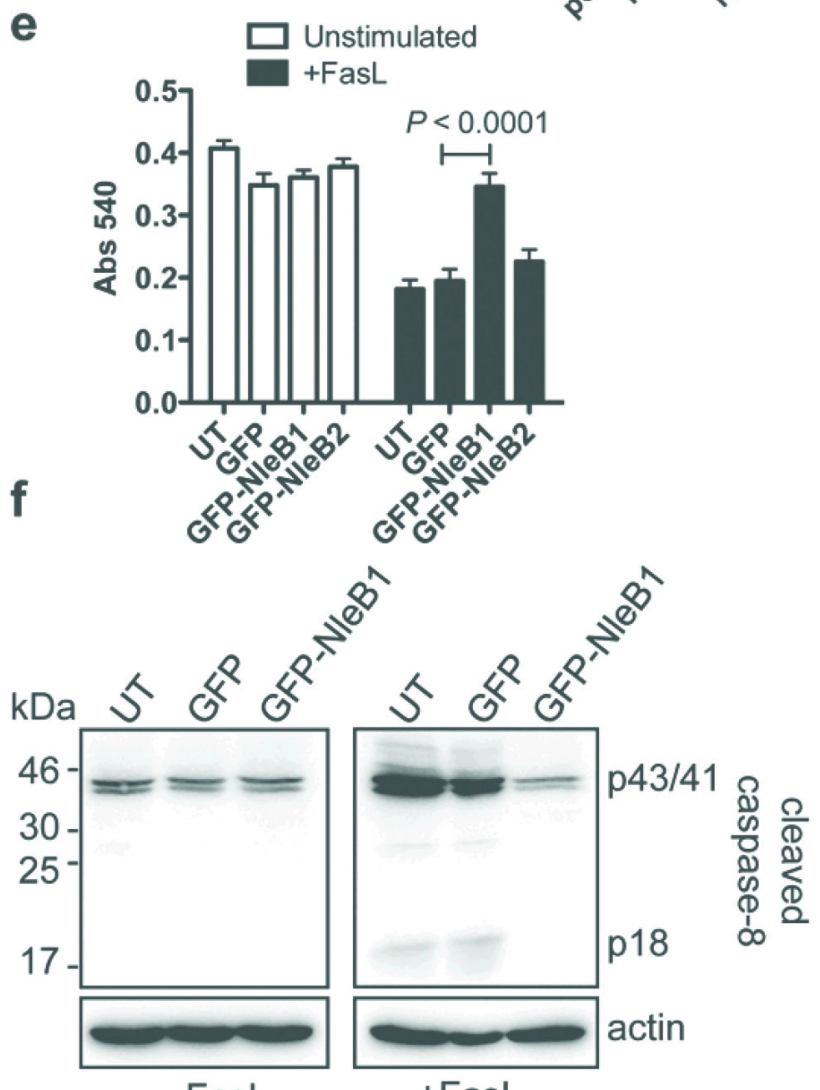

-FasL

+FasL

Figure 1. NleB1 binds death domain proteins and inhibits caspase-8 activation

a, Yeast two-hybrid analysis of protein-protein interactions in S. cerevisiae PJ69-4A.

Results are mean \pm SEM $\beta$-galactosidase activity from at least three independent experiments performed in triplicate. $\mathbf{b}$, Growth of S. cerevisiae PJ69-4A on medium to select for protein-protein interactions (left panel) or plasmid maintenance (right panel). Representative images from at least three independent experiments $\mathbf{c}$, Yeast two-hybrid analysis of protein interactions in S. cerevisiae PJ69-4A. Results are mean \pm SEM $\beta$ galactosidase activity from at least three independent experiments performed in triplicate. $\mathbf{d}$, 
GFP-Trap ${ }^{\circledR}$ of GFP-NleB1 and detection of FADD-FLAG, TRADD-FLAG and RIPK1FLAG in HEK293T cells. Actin; loading control. Representative immunoblot from at least three independent experiments e, MTT reduction in HeLa cells expressing GFP, GFP-NleB1 or GFP-NleB2. UT, untransfected. Results are the mean \pm SEM of absorbance at $540 \mathrm{~nm}$ from three independent experiments performed in triplicate. $* P<0.0001$, unpaired, twotailed $t$-test. f, Cleaved caspase- 8 in HeLa cells expressing GFP or GFP-NleB1.p43/41 and p18 are products of processed caspase- 8 . UT, untransfected. Representative immunoblot from at least three independent experiments. 


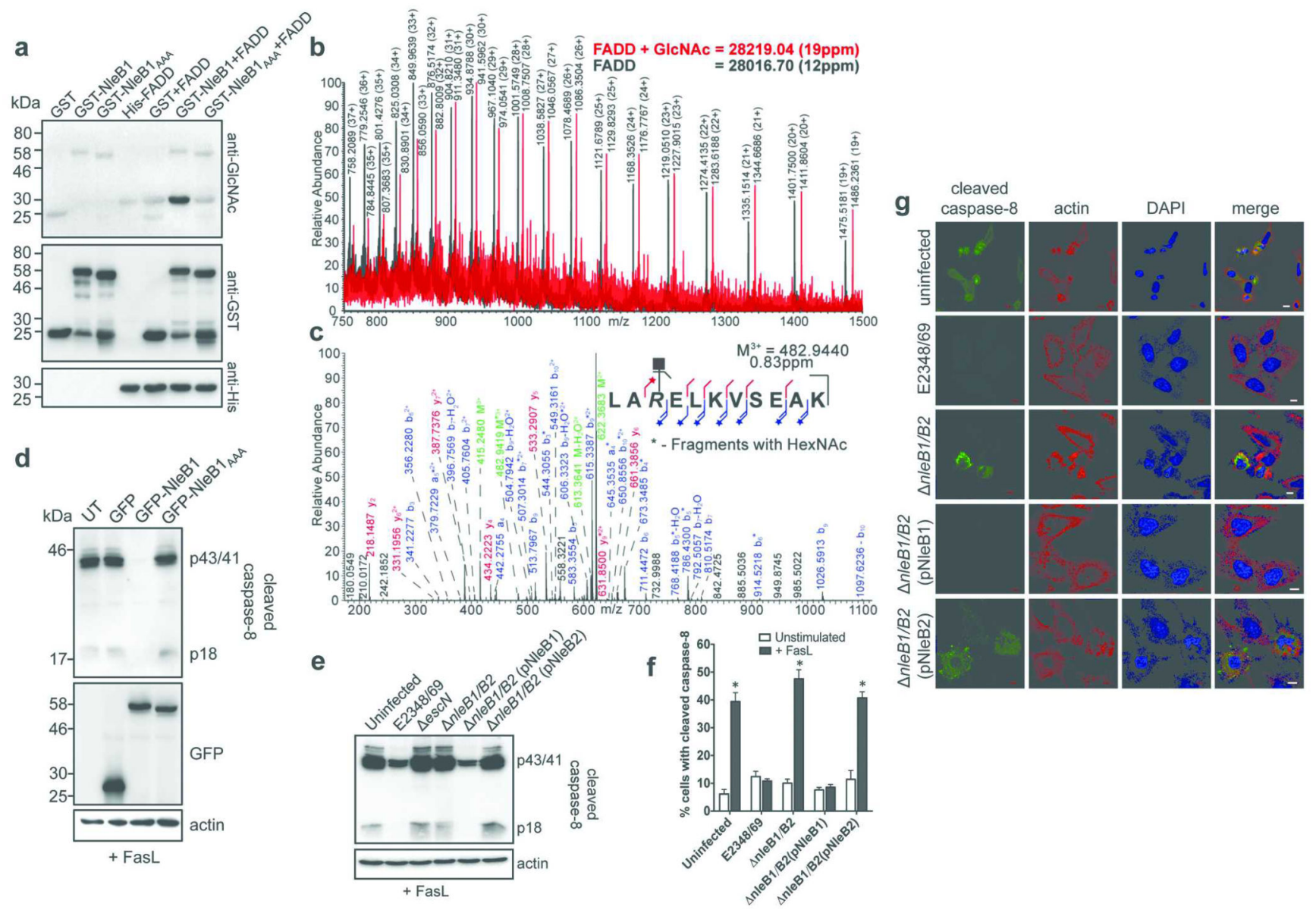

Figure 2. Enzymatic activity of NleB1

a, In vitro assay for NleB1 GlcNAc modification of FADD using recombinant proteins and $1 \mathrm{mM}$ UDP-GlcNAc. Representative immunoblot from at least three independent experiments b, Intact protein mass spectrometry of FADD incubated with GST-NleB1 and UDP-GlcNAc. c, High resolution CID spectrum of the peptide corresponding to FADD ${ }^{115-125}$. *Diagnostic fragment ions that carry the GlcNAc modification. d, Cleaved caspase-8 in FasL-treated HeLa cells expressing GFP, GFP-NleB1 or GFP-NleB1 AAA. UT, untransfected. Actin; loading control. Representative immunoblot from at least three independent experiments e, Cleaved caspase- 8 in HeLa cells infected with derivatives of EPEC and treated with FasL. Representative immunoblot from at least three independent experiments $\mathbf{f}$, Quantification of cleaved caspase- 8 by immunofluorescence microscopy of HeLa cells infected with derivatives of EPEC and treated with FasL. Results are mean \pm SEM percentage cells with cleaved caspase- 8 from two independent experiments counting $\sim 200$ cells in triplicate. $* P<0.0001$ compared to uninfected, unstimulated control, one-way ANOVA g, Immunofluorescence staining for detection of cleaved caspase- 8 induced by FasL in HeLa cells infected with derivatives of EPEC. Scale bar $10 \mu \mathrm{m}$. Representative images from at least three independent experiments 
a
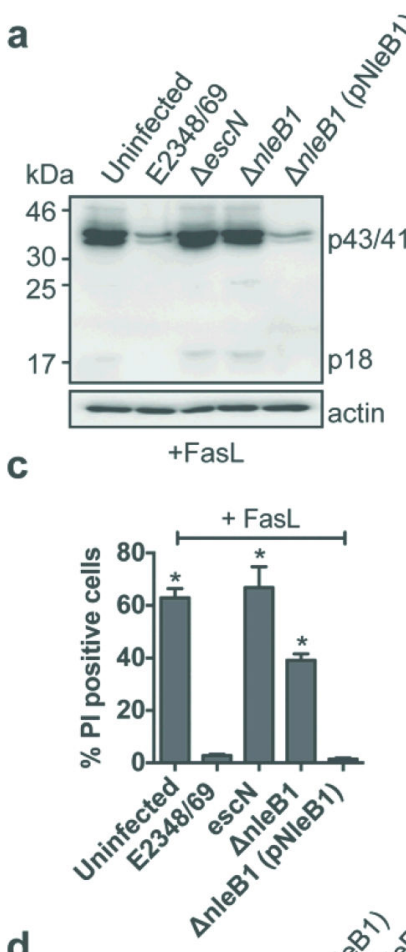

d
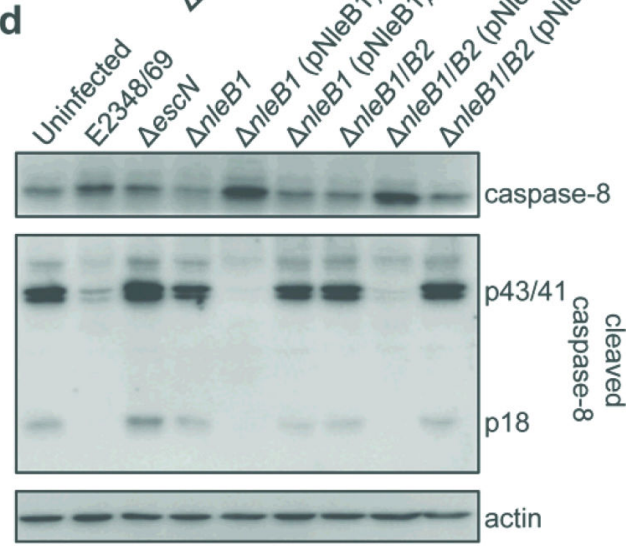

+ FasL

b

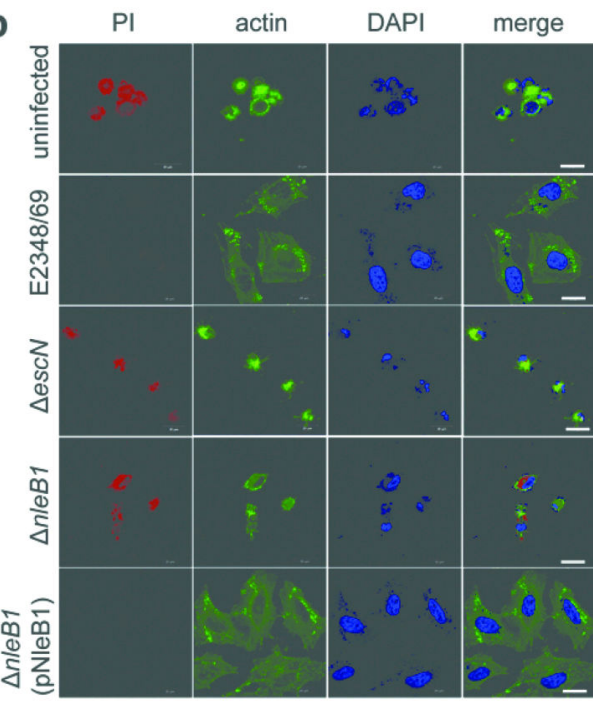

e

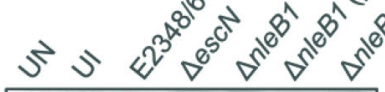

$\frac{n}{3}$

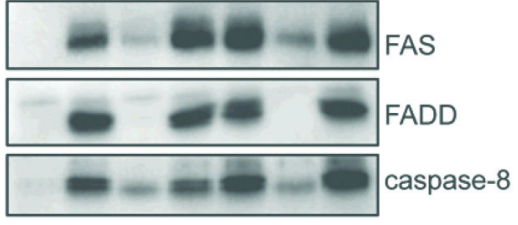

+ FasL

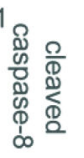

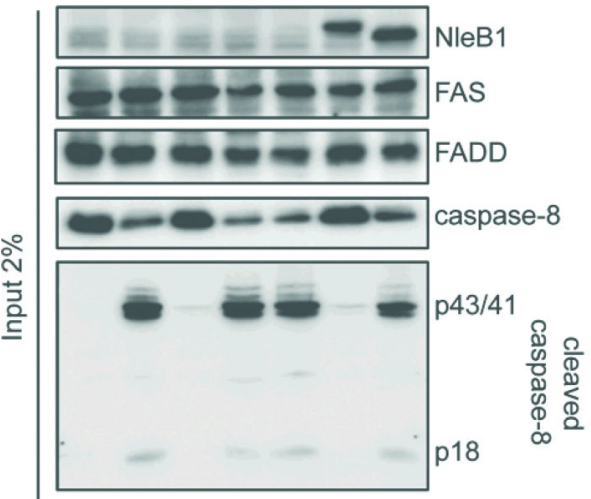

$--\infty$ actin

Figure 3. Inhibition of FasL-induced DISC formation and cell death by EPEC

a, Cleaved caspase-8 in HeLa cells infected with derivatives of EPEC. Actin; loading control. Representative immunoblot from at least three independent experiments $\mathbf{b}$, Cell death visualised by PI staining in HeLa cells infected with derivatives of EPEC and treated with FasL. Scale bar $20 \mu \mathrm{m}$. Representative images from at least three independent experiments $\mathbf{c}$, Quantification of PI staining and microscopic analysis in HeLa cells infected with derivatives of EPEC and treated with FasL. Results are mean \pm SEM percentage cells with PI staining from two independent experiments counting 200 cells in triplicate. ${ }^{*} P<$ 
0.0001 compared to E2348/69 infected cells, one-way ANOVA. d, Cleaved and full-length caspase- 8 in HeLa cells infected with derivatives of EPEC and treated with FasL. Actin; loading control. Representative immunoblot from at least three independent experiments e, DISC components induced by FasL coupled to $\mathrm{Fc} \delta$ and precipitated with protein $\mathrm{G}$ beads.

UN, untreated and uninfected; UI, uninfected. Actin; loading control. Representative immunoblot from at least three independent experiments. 

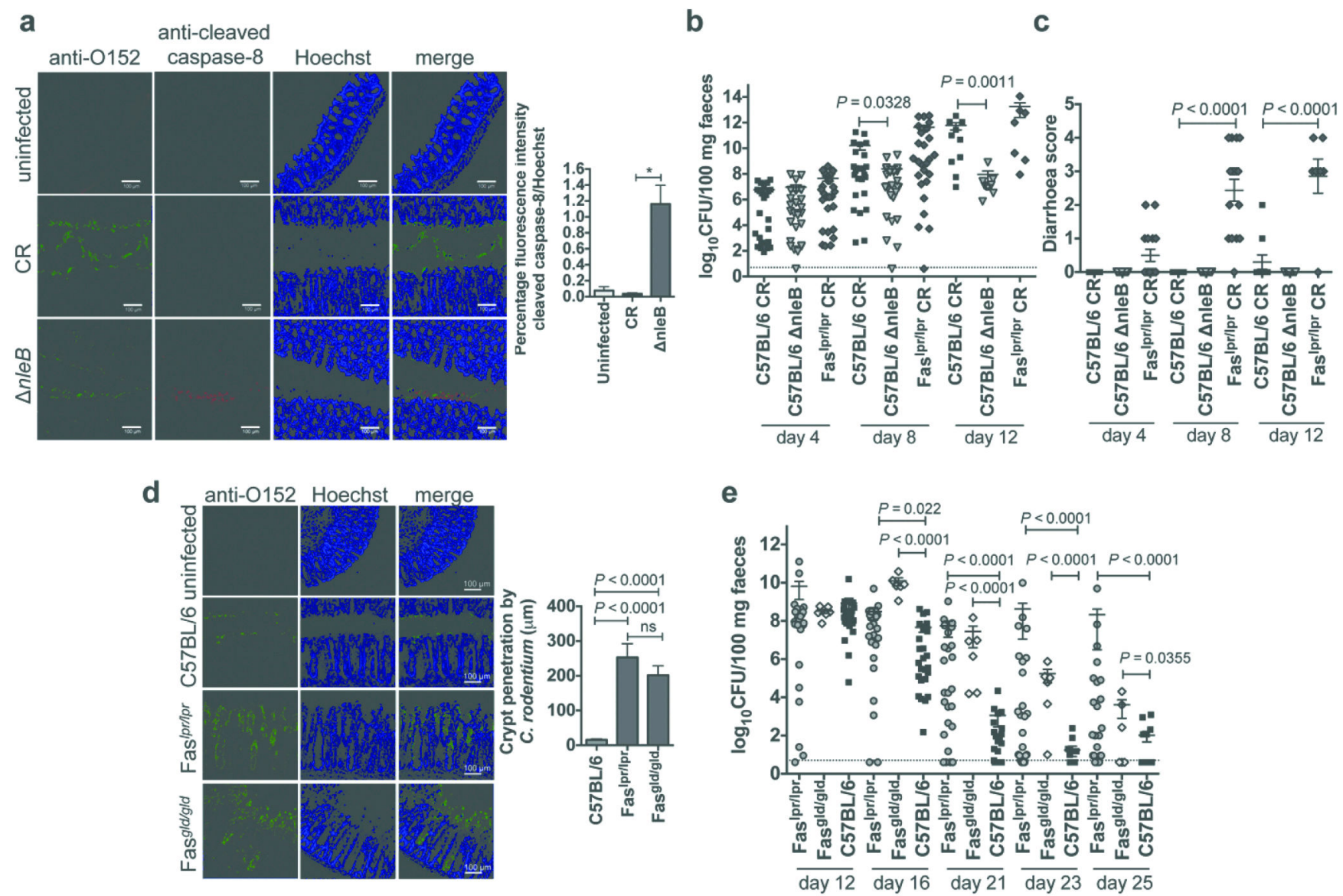

Figure 4. Infection of mice deficient for FAS signalling with CR

a, Immunofluorescence staining and quantification of cleaved caspase- 8 in colonic sections from $\mathrm{C} 57 \mathrm{BL} / 6$ mice infected with $\mathrm{CR}$ or a $\mathrm{CR} n l e B$ mutant. Representative images from at least three separate sections of colon at least $100 \mu \mathrm{m}$ apart (transverse or longitudinal), per animal from five individual mice per group. Results are mean \pm SEM percentage fluorescence intensity of cleaved caspase- 8 staining relative to Hoechst staining of five fields with CR infection from three mice per group. ${ }^{*} P=0.0001$, unpaired two tailed $t$-test.

b, Bacterial load in the faeces during acute infection with CR. Each data point represents $\log _{10} \mathrm{CFU} / 100 \mathrm{mg}$ faeces per individual animal on days 4, 8 and 12 after infection. Mean \pm SEM are indicated, dotted line represents detection limit. $P$ values from Mann Whitney U. c, Diarrhoea score at day 4, 8 and 12 post-infection. Scoring system is described in the Supplementary Methods. Mean \pm SEM are indicated. $P$ values from one-way ANOVA. d, Immunofluorescence staining and quantification of $\mathrm{CR}$ penetration into intestinal crypts in colonic sections from C57BL/6, Fas ${ }^{l p r / l p r}$ and Fas ${ }^{\text {gld/gld }}$ mice. Representative images from at least two separate sections of colon at least $100 \mu \mathrm{m}$ apart (transverse or longitudinal), per animal from five individual mice per group. Results are the mean \pm SEM maximum distance of CR staining from the epithelial surface (in $\mu \mathrm{m}$ ) of five independent sections with at least three measurements per section. $P=0.0001$, unpaired two tailed $t$-test. e, Bacterial load in the faeces during the resolving phase of $\mathrm{CR}$ infection. Each data point represents $\log _{10} \mathrm{CFU} / 100 \mathrm{mg}$ faeces per individual animal on days 12, 16, 21, 23 and 25 post-infection. 
Mean \pm SEM are indicated, dotted line represents detection limit. $P$ values from Mann Whitney U. 